\title{
Pedagogical Implications of Error Analysis on English Writing in the High School
}

\author{
Na Ming \\ China West Normal University, Nanchong, Sichuan, China
}

\begin{abstract}
As error analysis relating to English writing has been advanced, error analysis on English writing in the high school is much less concerned. Moreover, the great significance of English writing in the high school has been recognized by teachers and educators. And as an efficient and effective way to figure out students' mastery of English, error analysis has gained its popularity in the process of teaching English writing. Thus, it is necessary for teachers to pay attention to error analysis and apply it into their teaching.
\end{abstract}

Keywords: error analysis; English writing; high school; pedagogical implications

\section{Introduction}

For second language learners, writing is an important production activity, and its purpose is to use language for academic purposes or certain types of service functions. According to National English Curriculum Standards for General High School (2020) in China, writing has been an essential part of language ability to comprehend and express meaning in the social context. And errors can provide feedback. On the one hand, it helps to understand the sources and types of learners' errors so that teachers can carry out targeted remedial teaching to improve students' learning through error analysis. On the other hand, through error analysis, teachers can figure out the shortcomings of their teaching methods and teaching plans. Therefore, efforts have been made to concentrate on the study of error analysis, and English writing has benefited a lot from it in the recent years.

\section{Error Analysis}

\subsection{Error and mistake}

Error analysis (EA) is the first method to study second language acquisition. It focuses on the creative ability of learners to construct language, rather than based on the ideal language structure of the first language (L1) and second language native speakers. The conceptualization and significance of errors took on a different role with the publication of an article by Corder titled "The Significance of Learners' Errors". Unlike the typical views of teachers at the time, in Corder's view, mistakes should not only be regarded as something that should be eradicated, but also as an important thing has greatly changed teachers' traditional view on errors. In The Significance of Learners' Errors, Corder distinguished errors (which results from incomplete knowledge) from mistakes (which is caused by some processing failures like slips of the tongue). Mistakes are usually one-time-only events which L2 learners are capable of recognizing and correcting it. While errors can be seen as red flags, which provides a window into the system---that is, evidence of the learner's L2 knowledge status. However, there exists a dilemma of distinguishing between errors and mistakes in L2 acquisition.

Copyright (C) 2021 by author(s) and Frontier Scientific Research Publishing Inc.

This work is licensed under the Creative Commons Attribution International License (CC BY 4.0).

http://creativecommons.org/licenses/by/4.0/ 


\subsection{Steps of error analysis}

Corder proposed a procedure with five steps to analyze learners' errors: to collect sample of language learners; to identify errors; to describe errors; to explain errors, and to evaluate errors. While M. Gass and Selinker proposed many steps when performing error analysis, including collecting data, identifying errors, classifying errors, quantifying errors, analyzing sources, and remediating them.

\subsection{Sources of errors}

Interlingual errors (resulting from negative transfer or interference from L1) refer to errors caused by the learner's native language transfer. For instance, the incorrect French sentence "Elle regarde les" is written according to the English word order "She sees them" instead of the correct French sentence "Elle les regarde" ("She them sees"). Intralingual error (not attributable to cross-linguistic influence) results from faulty or partial learning of the target language, rather than language transfer. In addition, there are other factors which result in errors, such as context of learning, communication, cultural factors and personal factors .

\section{Errors in English Writing in the High School}

Lin, Duan and Zhang reviews the second language errors analysis of L2 writing in China from contents, objects to writing styles. The research objects and writing styles are relatively extensive, but researches on college students (74.8\%) are much more than middle school students. Research shows that the most common error types of high school English writing can be divided into ontology error, text error, and discourse error. Therefore, this research will focus on three types: ontology error, text error, and discourse error.

\subsection{Ontology errors}

Ontology errors include word spelling, punctuation and capitalization errors. Word spelling errors can be attributed to L2 learners' inadequacy of knowledge in vocabulary. Liu identified three factors accounting for punctuation errors: the negative transfer from native language, lack of knowledge in punctuation and illogical thinking and expression. Both word spelling and punctuation errors probably result from faulty or partial learning of English rather than from language transfer. Thus, both of them can be included in intralingual errors. However, the capitalization error is caused by the language conversion of Chinese, because Chinese is not capitalized.

\subsection{Text errors}

Text errors include lexical and grammatical errors. The most prominent lexical errors in English writing are lexical collocation, verbs, prepositions and nouns. While grammatical errors mainly focus on tense, voice, subject-verb agreement and inflectional changes.

\subsection{Discourse errors}

Discourse errors mainly include coherence and pragmatic errors, of which coherence is the most common. Students' lack of knowledge on coherence deeply restricts the accuracy of their writing.

\section{Pedagogical Implications}

Perhaps the most common justification for error analysis in L2 acquisition is that errors are considerably significant in L2 acquisition for both teachers and learners. Also, in the same influential article, Corder noted that errors could be of great significant in three aspects. First, they provided the teacher with information about how much the learner had learned. Second, they provided the researcher with evidence of how language was learned. Third, they served as devices by which the learner discovered the rules of the target language. Through error correction, teachers have made great contributions to the learning of second language learners.

Teachers should update their concepts of error analysis in the course of English writing teaching. In traditional 
English writing teaching, teachers regard English learners' errors as negative products and must be eradicated so that learners' texts are all corrections by teachers, which greatly hurts learners' confidence. Corder claimed that teachers should not regard L2 learners' errors as bad habits to be eradicated, but as sources of insight into the learning processes.

Evaluation of errors, one of the steps for analyzing learner errors which Corder suggests in error analysis, includes analyzing the impact of the error on the person being corrected. For example, how severe it is, or to what extent it affects clarity or social acceptance. For instance, the sentence "He are always late for school" ("he is always late") doesn't matter too much if address and addressee share a common text. Therefore, it is not necessary to correct the error as learners can discover the error themselves. However, if the error is easy to result in fossilization, teachers are responsible to correct them. This effect can be gauges either in terms of the addressee's comprehension of the learner's meaning or in terms of the addressee's affective response to the errors.

Teacher should correct students' errors in a flexible way. Lyster and Ranta summarized six types of the most common error correction methods: explicit correction, recast, clarification request, metalinguistic feedback, elicitation and repetition. Correction can be conducted by teacher-correction, peer correction and self-correction. However, there is a point needed to note that writing error analysis is usually carried out outside classroom, which means that there is a lack of face-to-face interaction between teachers and students. Therefore, it is advisable for teachers to combine teacher-correction with peer correction and self-correction properly so that learners are able to receive feedback from various perspectives.

Reading is one of the best ways to improve English writing. Only by effective language input can teachers ensure that students are able to output high-quality writings. Therefore, teacher should encourage students to read authentic English materials extensively so that students are able to enrich their knowledge of authentic expressions and strengthen their sense of English.

\section{Conflicts of Interest}

The author declares no conflicts of interest regarding the publication of this paper.

\section{References}

[1] Saville T. and Muriel (2012). Introducing Second Language Acquisition. Cambridge University Press, New York.

[2] The Ministry of Education of the People's Republic of China. (2020). General High School English Curriculum Standards (2017 Edition, Revised in 2020). People's Education Press, Beijing.

[3] Gass S. M. and Selinker L. (2008). Second Language Acquisition: An Introductory Course (3rd Edition). Routledge, New York.

[4] Corder S. P. (1974). Error Analysis. The Edinburgh Course in Applied Linguistics (Vol. 3). OUP, London.

[5] Jack C. R. and Richard S. (2002). Longman Dictionary of Language Teaching \& Applied Linguistics. Foreign Language Teaching \& Research Press, Beijing.

[6] Lin D.M., Duan M.J. and Zhang H.Y. (2019). A Review of Domestic Second Language Writing Errors Analysis Research. Journal of Leshan Normal University, 34(09): 31-36.

[7] Liu B. (2005). Analysis of Punctuation Errors in English Writing. Journal of Hunan University of Science and Technology, (09): 288-289.

[8] Ellis R. (1999). The Study of Second Language Acquisition. Shanghai Foreign Language Education Press, Shanghai.

[9] Lyster R. and Ranta L. (1997). Corrective Feedback and Learner Uptake: Negotiation of Form in Communicative Classrooms. Studies in Second Language Acquisition, (20): 37-66. 